\title{
The Effect of Being Planned Pregnancy and Number of Pregnancies on Social Appearance Anxiety Level of Pregnant Women
}

\section{Gebeliğin Planlı Olma Durumu Ve Gebelik Sayısının Gebelerdeki Sosyal Görünüş Kaygı Düzeyine Etkisi}

\author{
(1) Sumeyye Altiparmak', @Ayse Nur Yilmaz² \\ 'Inonu University, Faculty of Health Sciences, Department of Midwifery, Malatya, Turkey \\ ${ }^{2}$ Firat University, Faculty of Health Sciences, Department of Midwifery, Elazig, Turkey \\ Copyright@Author(s) - Available online at www.dergipark.org.tr/tr/pub/medr \\ Content of this journal is licensed under a Creative Commons Attribution-NonCommercial 4.0 International License
}

\begin{abstract}
Aim: In this study, it was aimed to examine the effect of being planned pregnancy and number of pregnancies on the social appearance anxiety level of pregnant women.

Material and Method: Cross-sectional nature of the sample of the research conducted in a public hospital in eastern Turkey has created 426 pregnant women who were admitted for routine examination. The data were collected using "Personal Information Form" and "Social Appearance Anxiety Scale (SAAS)". In statistical evaluation; In addition to descriptive statistics (number, percentage, mean, standard deviation, min-max), Cronbach's alpha, pearson correlation, chi-square and independent groups $t$ test were used.

Results: In this study, it was determined that social appearance anxiety during pregnancy was not affected by the number of pregnancies, but women who had an unplanned pregnancy had a higher level of social appearance anxiety compared to women who had a planned pregnancy $(p=0.008)$. In addition, it was found that primary school graduates had a significantly higher level of social appearance anxiety than high school and university graduates $(p=0.009)$. It was observed that as the age and gestational week of the pregnant increased, their social appearance anxiety levels decreased significantly $(p=0.002 ; p=0.039$, respectively). It was determined that pregnant women whose income was less than their expenses had a higher level of social appearance anxiety compared to pregnant women with a traditional family structure compared to those with a nuclear family structure $(p=0.036 ; p=0.008$, respectively).

Conclusion: In this study, social appearance anxiety in pregnant women was not affected by the number of pregnancies. However, social appearance anxiety was experienced more in unplanned pregnancies and social appearance anxiety during pregnancy was affected by age, educational status, economic status, family structure and gestational week.
\end{abstract}

Keywords: Planned pregnancy; number of pregnancies; social appearance anxiety

Öz

Amaç: Bu araştırmada, gebeliğin planlı olma durumu ve gebelik sayısının gebelerdeki sosyal görünüş kaygı düzeyine etkisini incelemek amaçlanmıştır.

Materyal ve Metot: Kesitsel nitelikte yapılan araştırmanın örneklemini Türkiye'nin doğusundaki bir kamu hastanesine rutin muayene için müracaat eden 426 gebe oluşturmuştur. Veriler, "Kişisel Tanıtım Formu" ve "Sosyal Görünüş Kaygısı Ölçeği (SGKÖ)" ile toplanmıştır. İstatistiksel değerlendirmede; tanımlayıcı istatistiklerin (sayı, yüzde, ortalama, standart sapma, min-max) yanı sıra, Cronbach's alfa, pearson korelasyon, ki-kare ve bağımsız gruplarda t testi kullanılmıştır.

Bulgular. Bu araştırmada gebelikteki sosyal görünüş kaygısının gebelik sayısından etkilenmediği ancak plansız gebelik yaşayan kadınların planlı gebelik yaşayan kadınlara oranla daha yüksek sosyal görünüş kaygı düzeyine sahip olduğu belirlendi $(p=0.008)$. Ayrıca ilkokul mezunu gebelerin lise ve üniversite mezunu gebelerden anlamlı düzeyde daha yüksek sosyal görünüş kaygı düzeyine sahip

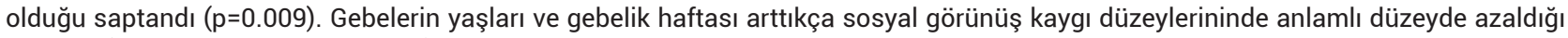
görüldü (sırasıyla $p=0.002 ; p=0.039$ ). Geliri giderden az olan gebelerin geliri giderinden fazla olan gebelere oranla ve geleneksel aile yapısına sahip olan gebelerin çekirdek aile yapısına sahip olanlara oranla daha yüksek sosyal görünüş kaygı düzeyine sahip olduğu belirlendi (sırasıyla $p=0.036 ; p=0.008$ ).

Sonuç: Bu araştırmada gebelerdeki sosyal görünüş kaygısı gebelik sayısından etkilenmemiştir. Fakat plansız gebeliklerde daha fazla sosyal görünüş kaygısı yaşanmış ve gebelikte sosyal görünüş kaygısı yaş, eğitim durumu, ekonomik durum, aile yapısı ve gebelik haftasından etkilenmiştir.

Anahtar Kelimeler. Planlı gebelik; gebelik sayısı; sosyal görünüş kaygısı

Geliş Tarihi / Received: 21.01.2021 Kabul Tarihi / Accepted: 17.02.2021

Sorumlu Yazar /Corresponding Author. Sumeyye Altiparmak, Inonu University, Faculty of Health

Sciences, Department of Midwifery, Malatya, Turkey. E-mail: sumeyye.kandemir@inonu.edu.tr 


\section{INTRODUCTION}

Individuals' evaluations about the meaning and appearance they attribute to appearance have always come to the fore in social settings. Nowadays people became more interested in their own appearance and in other people's appearance than in past times. This situation brought about individuals to evaluate their physical appearance as good or bad (1).

Having a negative perception of an individual's appearance and body image causes social appearance anxiety (1). Individuals' negative thoughts towards their own body are defined as social appearance anxiety (2-4). It also includes the sadness felt about the physical appearance of the person and the anxiety felt about being evaluated by other people, which occurs with different problems and causes the individual to be negatively affected in daily life (4). Some people think that they like the physical appearance of others or do not care about the thoughts of others about their physical appearance and therefore rarely experience social appearance anxiety $(2,5)$. Some people are very concerned about social appearance. These concerns are known to be a holistic and general concern that arises not only from the physical appearance of the people, but also from reasons such as height, weight, face shape, and clothing style (1).

People who have social appearance anxiety think that they cannot make a good impression by paying too much attention to what other people will comment on them and therefore experience anxiety (4). If these individuals fail to make a good impression, they may feel disappointed and experience sadness $(1,4)$. In people with social appearance anxiety, in addition to symptoms such as avoidance of interacting with other people, restlessness, concentration disorder, impaired speech fluency, and tremors, secondary symptoms such as flushing, nausea, and urinary urgency may occur (5). Sometimes, when people believe that these secondary symptoms are problem, symptoms can progress and cause panic attacks, and in more extreme cases, social isolation can be experienced almost completely (5). When people are not satisfied with their external appearance, they may have lower self-esteem, more pessimistic, insecure, and depressed mood. People who are happy with their physical appearance can have a more social, happy and self-confident mood (4).

It has been found that individuals experience intense social appearance anxiety in some periods of their lives, including adolescence $(6,7)$. It is known that women experience discomfort mostly during pregnancy due to their external appearance $(8,9)$. Pregnancy, which is one of the most important stages of women's life. Pregnancy brings along many physiological, psychological and social changes in each trimester $(8,13)$.

Studies have reported that many factors can have an effect on body image and social appearance anxiety during pregnancy $(13,14)$. In the studies; factors such as first gestational age, experience of miscarriage and curettage, live birth experience, time between previous pregnancy and this pregnancy $(8,12,15,16)$. However, the number of studies dealing with obstetric variables such as the number of pregnancies and the planned pregnancy is limited $(13,14,17)$. In these limited studies, different findings have been obtained indicating that body image may have positive or negative effects in those who become pregnant for the first time. Therefore, the increase in the number of pregnancies can be considered as an important variable in social vision anxiety. In addition, it is reported that another factor that has an effect on social appearance perception is the meaning given to pregnancy and it is stated that women who have a planned pregnancy perceive pregnancy more positively $(13,14,17)$. Based on this information, it is thought that examining the effect of the number of pregnancies and the planned pregnancy status on the social appearance anxiety level of pregnant women will contribute to the literature. In this study, it was aimed to determine the effect of the number of pregnancies and planned pregnancy on the social appearance anxiety level of pregnant women.

\section{MATERIAL AND METHODS}

This cross-sectional study was conducted in order to determine the effect of the number of pregnancies and the planned pregnancy on the social appearance anxiety level of pregnant women.

The population of the study was composed of pregnant women who applied to a public hospital for routine examination in easten Turkey between 1 December 2020 and 15 January 2021. The sample of the study consisted of 426 pregnant women who met the inclusion criteria.

\section{Study Inclusion Criteria}

All pregnant women who had internet access, do not have a risky pregnancy had no psychiatric health issues and were not diagnosed with COVID 19 were included in the study.

\section{Data Collection Tools}

Data were collected using a "Personal Information Form" and "Social Appearance Anxiety Scale (SAAS)".

\section{Personal Information Form}

This form prepared by the researchers, consists of a total of 8 questions about the 5 questions about the sociodemographic characteristics (age, educational status, work status, economic status, etc.) of the pregnant women and 3 questions about the obstetric characteristics (gestational week, number of pregnancies and planning of pregnancy) (8-10).

\section{Social Appearance Anxiety Scale (SAAS)}

The Turkish adaptation of this scale, which was developed by Hart et al. (2008), was made by Doğan $(2010)(2,3)$. The one-dimensional scale consists of 16 items and is used to measure individuals' social appearance anxiety. Scoring is evaluated by calculating the total score and the scores range between 16 and 80 points. High scores show that social appearance anxiety is high. Item 1 of the scale is reverse coded. The Cronbach Alpha reliability coefficient of the scale was found to be 0.93 (3). In our study, the Cronbach Alpha reliability coefficient was found as 0.89 . 


\section{Data Collection}

Research data were obtained from pregnant women who came for routine examination and accepted to participate in the study on weekdays. Due to the Covid-19 pandemic process, the Google Forms method was used. Informed consent forms and data collection tools were sent to the pregnant women who met the research criteria using a mobile phone with internet access. The data recorded by pregnant women were stored on the Google Forms data network. Data collection from each pregnant woman lasted around 5-10 minutes.

\section{Data Analysis}

For the data analzying were used, the SPSS 20.0 package program (Statistical Package for the Social Sciences Inc., Chicago, IL, USA). Arithmetic mean, standard deviation, percentage distribution, Cronbach's alpha, Pearson correlation, chi-square and independent groups $t$ test were used in statistical evaluation. The results were evaluated using a 95\% confidence interval, which represents a significance level of $0.05(p<0.05)$.

\section{Ethical Considerations}

For conducting the study, ethical approval was obtained from the Health Sciences Scientific Research and Publication Ethics Committee at Inonu University (Decision No: 2020/1312) and institutional permission from Firat University Hospital. All pregnant women were asked to sign an informed consent form via the Internet before starting the research.

\section{RESULTS}

The examination of the social appearance anxiety levels of pregnant women in terms of descriptive characteristics is given in Table 1. The mean of the SAAS total score of all pregnant women was $35.97 \pm 0.98$. The mean average age of the pregnant women was $28.72 \pm 5.92$ years, the mean of gestational age was $31.44 \pm 7.52$ weeks, and the mean duration of marriage was $6.64 \pm 5.40$ years. It was determined that $31.2 \%$ of the pregnant women were primary school, $81.2 \%$ did not working/housewifes, $79.8 \%$ had a nuclear family, and $71.8 \%$ of them were income and expense equivalent.

It was determined that as the age and gestational week of the pregnant increased, the social appearance anxiety levels decreased significantly $(t=-0.147 ; p=0.002 ; t=-$ $0.100 ; p=0.039$, respectively).

When the total score averages from SAAS according to the education status of pregnant women were compared; It was found that primary school graduates had a significantly higher level of social appearance anxiety than high school and university graduates $(F=3.879 ; p=0.009$; $a>c, d)$.

Table 1. The examination of the social appearance anxiety levels of the pregnant women in terms of the descriptive characteristics $(n=426)$

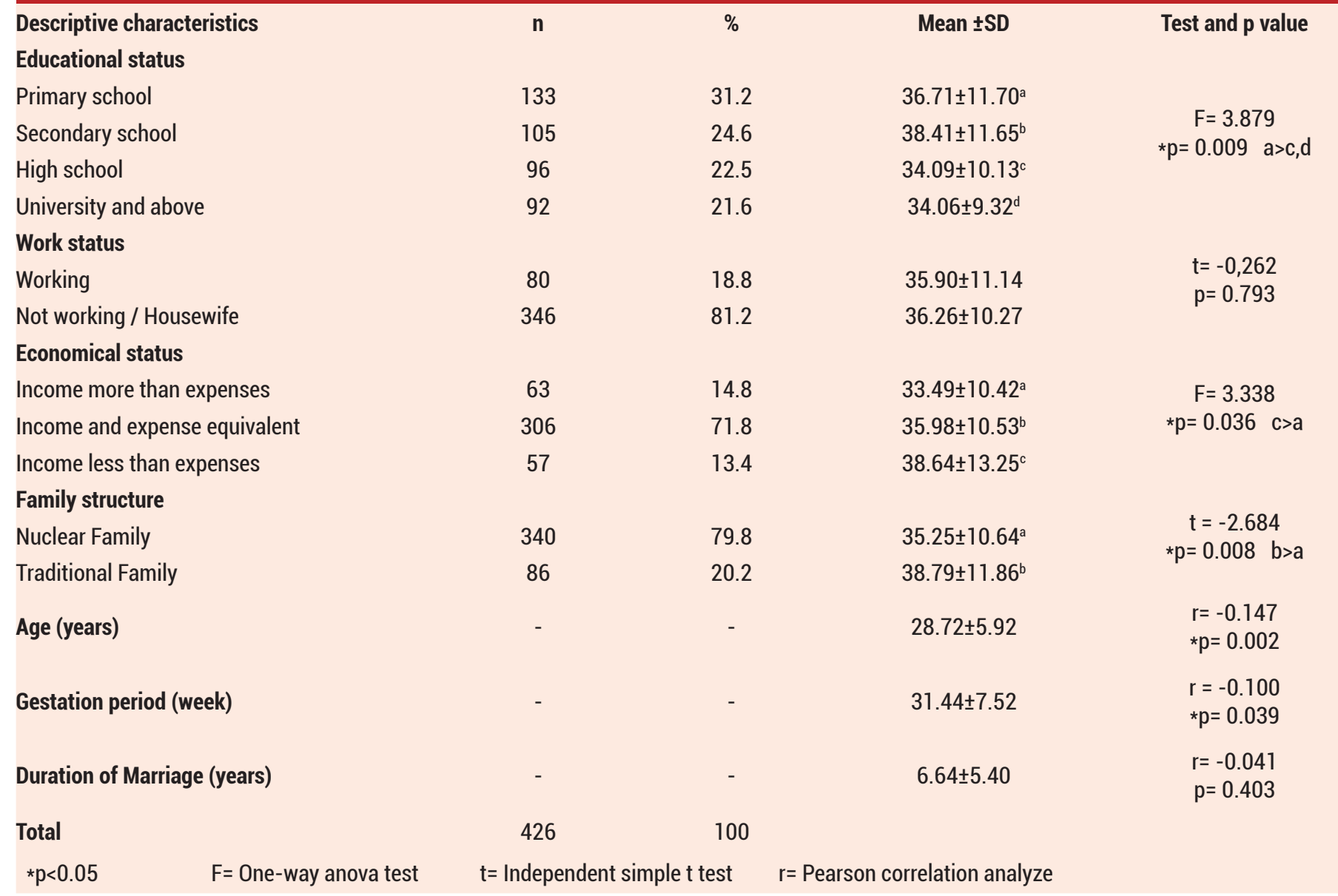


When the total score averages from SAAS according to the economical situation of pregnant women were compared; It was determined that the pregnant women whose revenue is less than expenses had a significantly higher level of social appearance anxiety than those Income more than expenses $(F=3.338 ; p=0.036 ; c>a)$. In addition, It was found that pregnant women with traditional families had higher social appearance anxiety level than pregnant women with nuclear families $(t=-2.684 ; p=0.008 ; b>a)$.

The examination of the social appearance anxiety levels of pregnant women in terms of the number of pregnancies and the planned pregnancy status is given in Table 2 . It was found that $68.3 \%$ of the pregnant women had multigravida and $69.5 \%$ had planned pregnancy.

When the total mean scores from SAAS of the participants were compared according to the number of pregnancies, it was found that there was no statistically significant difference between the groups $(t=-0.262 ; p=0.793)$.

When the total score averages from SAAS according to the planned pregnancy status were compared; It was determined that those who had unplanned pregnancies had a significantly higher level of social appearance anxiety compared to those who had a planned pregnancy $(t=-2.670 ; p=0.008 ; b>a)$.

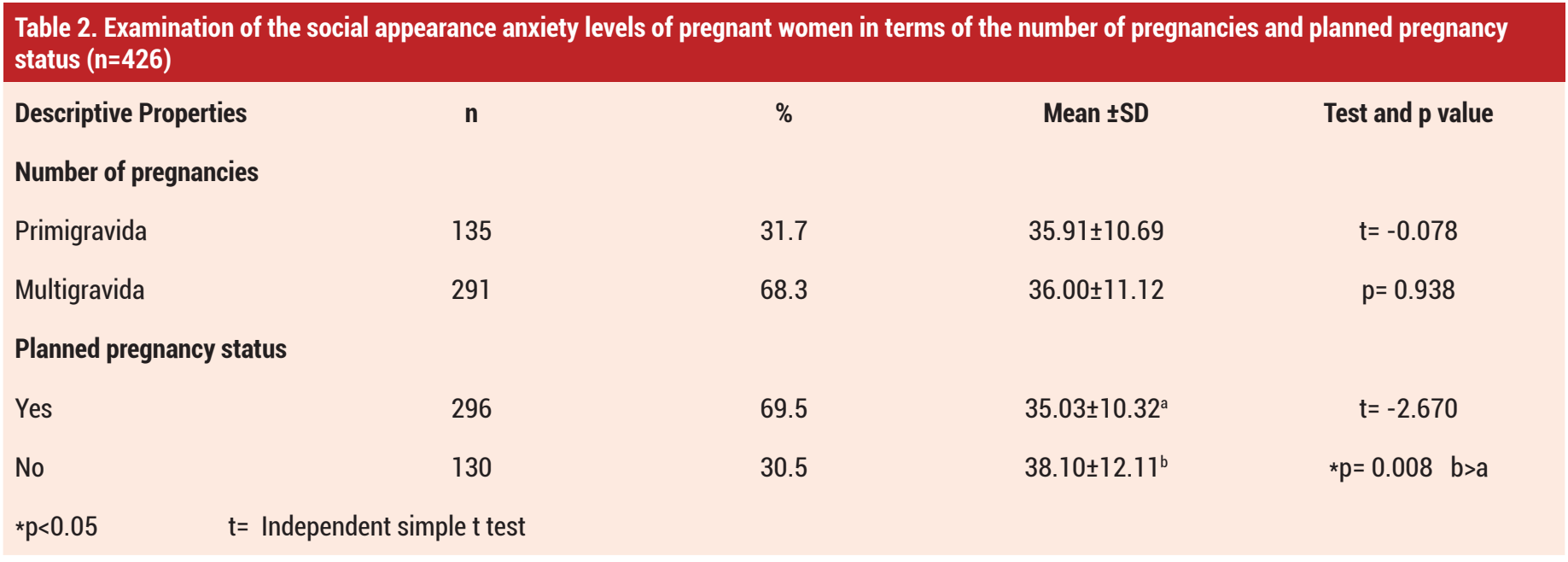

\section{DISCUSSION}

Physiological, psychological and social changes that occur as the pregnancy progresses cause women to perceive their appearance positively or negatively. Especially, the changes in women's appearance may cause the woman to perceive herself differently and feel incompetent and unattractive. As a result of these changes, a woman's self-confidence and self-esteem may decrease and body image may be negatively affected. In this section, the findings of the study conducted to determine the effect of the number of pregnancies and the planned pregnancy on social appearance anxiety levels are discussed with the relevant literature. When the literature was examined, it was not found that the SAAS scale was used in pregnant women. Therefore, the study findings were discussed with the results of the study including body image.

In our study, it was found that the mean age of pregnant women was $28.72 \pm 5.92$ years and their social appearance anxiety levels decreased with increasing age (Table 1). When the literature is examined, it has been determined that there are similar results to our findings and older pregnant women have a better body image ( 8 , $18,19)$. In addition, there are studies in the literature that different results have been obtained, such as that the ages of pregnant women are not related to their external appearance $(12,13,16,20-24)$, that is, body image, or that young pregnant women have a better $(8,17,25)$ or worse (26) body image. It can be said that this difference in the literature is due to the individual characteristics of pregnant women.

In our study, the average week of gestation of pregnant women was found to be $31.44 \pm 7.52$ and it was found that social appearance anxiety levels decreased as the week increased (Table 1). When pregnancy is learned, the attention of the pregnant woman is mostly on herself and the woman is anxious because even the slightest change in her body will affect her external appearance and body image. However, as the pregnancy progresses, the woman will begin to get used to the effects of pregnancy. His attention in the early pregnancy will gradually shift to the baby and the birth. This will bring along the absence of external appearance and body image anxiety during advanced pregnancy weeks $(8,14,26)$. When evaluated in this respect, it can be said that the finding obtained is compatible with the literature. However, there are studies showing that the gestational week does not affect the external appearance so body image (8, 12-17), and there are different studies showing that as the week of gestation increases, the external appearance or body image anxiety increases $(8,20,27-31)$. This difference in the literature is explained by the fact that the abdominal region becomes more prominent in the last months 
of pregnancy, significant changes such as swelling, weight gain, limitation of movement affect the external appearance and body image more, and it is emphasized that the body image of pregnant women is also affected by other personal characteristics.

In our study, it was determined that primary school graduates had more social appearance anxiety than high school and university graduates (Table 1). When the literature is examined, similar studies have been found showing that as the education levels of pregnant women increase, their body image perceptions also increase $(8,14,28,31)$. In addition, in this study, it was found that pregnant women with poor economic status experience more social appearance anxiety (Table 1). When the studies conducted are examined, it is stated that pregnant women with poor economic conditions experience more body image anxiety $(8,12-14,17,22,28$, $32,33)$. It can be said that individuals whose economic level has increased will have more comfortable access to opportunities such as clothing, cosmetics and care products that are thought to support their body image and it can be said that this situation may increase the body image perception.

In our study, it was found that pregnant women with traditional families experience more social appearance and body image anxiety (Table 1). Looking at the result in terms of family structure, it can be said that the pregnant woman spends less time for herself in the traditional (extended) family, has more roles and responsibilities, and is more tired because the number of members and workload in the family is higher. For these reasons, she may spend less time on herself and her body image may be lower. When the literature was reviewed, Gür (2020) stated in her study that, similar to our finding, pregnant women with nuclear families experienced less anxiety about external appearance, namely body image. It can be said that the obtained finding is compatible with the literature (8).

In this study, it was found that the number of pregnancies was not effective on social appearance anxiety, whereas those with unplanned pregnancy had higher social appearance anxiety, namely body image anxiety (Table 2). When the literature was examined, similar to our findings, body images of pregnant women with planned pregnancy were found to be higher than those of unplanned $(13,14,17,20,34)$. Women who have planned pregnancy and who become pregnant willingly perceive pregnancy more positively $(13,17)$. Pregnancy perception, which makes a difference for every woman and her family, is affected by many factors. Among these factors are included education level, socioeconomic level, personal experiences, state of being ready for motherhood, expectations and dreams from pregnancy, desire and planning of pregnancy $(13,17,35-37)$. The body and pregnancy perceptions of women who feel ready for pregnancy, who think that pregnancy is a unique period, and who are happy to bring a baby to the world, in short, who have accepted their pregnancy, are positively affected $(35,38)$. This positive perception also affects the meaning attributed to the physical changes that occur during pregnancy. In a desired pregnancy, conditions such as weight gain and skin changes in the mother's body are perceived as normal and temporary $(11,39)$. In this case, the body image perception of the woman will also increase. However, it has also been determined that experiencing situations such as having an unplanned pregnancy and not receiving adequate spousal support brings with it much more physical and emotional complaints and causes women to experience negative body image perceptions $(34,35,37)$.

\section{Limitations of the Research}

This study is limited to pregnant women in a province located in eastern Turkey.

\section{CONCLUSION}

In this study, the social appearance anxiety during pregnancy is affected by age, educational status, economic status, family structure, week of gestation and planning of pregnancy. Healthcare professionals, who are in closer and continuous communication with pregnant women, should take a holistic approach during the evaluation of pregnant women and all the physical and psychological effects of pregnancy on women should be reviewed. For this purpose, while providing quality care to pregnant women, it should be with the pregnant woman at each stage of the adaptation process to body changes during pregnancy, and planning should be made about how the body image is affected and how the pregnant woman will respond to this despite the changing body image. In addition, it should determine how to help the pregnant woman to cope with the change, and the pregnant woman should be provided with training and counseling on this issue.

\section{Acknowledgements}

We would like to thank the pregnant women who participated in this study.

Financial disclosures: All authors report no financial interests or potential conflicts of interest.

Conflict of Interest: The authors declare that they have no competing interest.

Ethical approval

Inonu University

Health Sciences Non-Interventional Clinical Research

Ethics Committee (Approval number $=$ 2020/1312).

\section{REFERENCES}

1. Kılıc M, Karakus $\mathrm{O}$. The study of the relationships between social appearance anxiety, self-esteem and loneliness leve among university students. J Human Sci 2016;13:3837-52.

2. Hart TA, Flora DB, Palyo SA, et al. Development and examination of the social appearance anxiety scale. Assessment 2008;15:48-59.

3. Dogan T. Adaptation of The Social Appearance Anxiety Scale (SAAS) to Turkısh: A valıdıty and reliability study. $\mathrm{H} U$ 
J Edu 2010;39:151-9.

4. Yucesoy 0 . The precurser relations among the values which the university students have their social appearance anxiety and their irrational belief. Master's thesis, Istanbul Sabahattin Zaim University, Istanbul, 2019.

5. Ismail M. Sexual self-schema and social appearance anxiety as predictors of happiness. Master's thesis, Istanbul Ticaret University, Istanbul, 2018.

6. Alemdag S, Oncu E. The investigation of participation physical activity and social appearance anxiety at the preservice teachers. Int J Sport Culture Sci 2015; 3:287-300.

7. Makas S, Celik E. Investıgatıon of relatıonshıps between early maladaptıve Schemas and social appearance anxiety. Electronic J Social Sci 2018;17:926-37.

8. Gur EY, Pasinlioğlu T. Determınıng status of perception of the pregnant women regarding body image during pregnancy. J Midwifery Health Sci 2020;3:71-81.

9. Aksoy Derya $Y$, Gok Ugur H, Ozsahin Z. Effects of demographic and obstetric variables with body image on sexual dysfunction in pregnancy: A cross sectional and comparative study. Int J Nurs Pract 2020; e12829.

10. Demir E. Determination of the effect of sociodemographic characteristics of pregnant women on ordinary complaints and quality of life in pregnancy. Master's Thesis, Erzincan Binali Yıldırım University, Erzincan, 2019.

11. Inanir S, Cakmak B, Nacar MC, et. al. Body Image perception and self-esteem during pregnancy. Int J Women's Health Reproduction Sci 2015;3:196-200.

12. Babacan Gumus A, Cevik N, Hataf Hyusni S, et.al. Characteristics associated with self-esteem and body Image In pregnancy. Anatol J Clin Investig 2011; 5:7-14.

13. Cirak R, Ozdemir F. Determınatıon of body image perception in pregnancy of adolesan. Anatol $J$ Nurs Health Sci 2015;18:214-21.

14. Kok G, Guvenc G, Bilsel H, et. al. Does Body Image Perceptions of Women Differ During Pregnancy? HEAD 2018;15:209-14.

15. Sagiroglu A. The relationship between body image, pregnancy, and birth fear and self-esteem during pregnancy. Master's Thesis, Üsküdar University, Istanbul, 2019.

16. Ozkan TK, Kucukkelepce DS, Ozkan SA. The relationship between prenatal attachment and body Image during pregnancy and affecting factors. CBU-SBED 2020;7:49-54.

17. Kumcagiz H. Pregnant women, body image and self-esteem according to the examination of some of the variables. J Human Sci 2012;9:691-703.

18. Gurung RA, Dunkel-Schetter C, Collins N, et. al. Psychosocial predictors of prenatal anxiety. J Social Clin Psychol 2005;24:497-519.

19. Glazier RH, Elgar FJ, Goel V, et. al. Stress, social support, and emotional distress in a community sample of pregnant women. J Psychosom Obstet Gynecol 2004;25:247-255.

20. Gozuyilmaz AY, Baran GTD. A research on body-ımage and self-esteem ın marrıed adolescents accordıng to pregnancy. Ph.D. dissertation, Ankara University, Ankara, 2011.

21. Arch JJ. Pregnancy-specific anxiety: which women are highest and what are the alcohol-related risks? Compr Psychiatry 2013;54:217-228.

22. Eryılmaz S. Determining the relationship between body image and depressive behaviors during pregnancy. Master's thesis, Eskişehir Osman Gazi Unıversıty. Eskişehir, 2017.
23. Mudra S, Göbel A, Barkmann C, et. al. The longitudinal course of pregnancy-related anxiety in parous and nulliparous women and its association with symptoms of social and generalized anxiety. J Affective Disorders 2020;260:111-8.

24. Insan N, Slack E, Heslehurst N, et. al. Antenatal depression and anxiety and early pregnancy BMI among White British and South Asian women: retrospective analysis of data from the Born in Bradford cohort. BMC Pregnancy and Childbirth 2020;20:502.

25. Madhavanprabhakaran GK, D'Souza MS, Nairy KS. Prevalence of pregnancy anxiety and associated factors. International J Africa Nursing Sci 2015;3:1-7.

26. Roomruangwong C, Kanchanatawan B, Sirivichayakul S, et. al. High incidence of body image dissatisfaction in pregnancy and the postnatal period: Associations with depression, anxiety, body mass index and weight gain during pregnancy. Sexual Reproductive Healthcare 2017;13:103-9.

27. Johnson M P, Baker SR. Implications of coping repertoire as predictors of men's stress, anxiety and depression following pregnancy, childbirth and miscarriage: a longitudinal study. J Psychosom Obstet Gynecol 2004; 25:87-98.

28. Skouteris H, Carr R, Wertheim EH, et. al. A prospective study of factors that lead to body dissatisfaction during pregnancy. Body Image 2005;2:347-61.

29. DiPietro JA, Millet S, Costigan KA, et. al. Psychosocial influences on weight gain attitudes and behaviors during pregnancy. J Am Dietetic Association 2003;103:1314-19.

30. Huang $\mathrm{HC}$, Wang SY, Chen $\mathrm{CH}$. Body image, maternal fetal attachment, and choice of infant feeding method: a study in Taiwan. Birth 2004;31:183-8.

31. Nash M. Weighty matters: Negotiating 'fatness' and 'inbetweenness' in early pregnancy. Feminism Psychol 2012;22:307-23.

32. Duncombe D, Wertheim EH, Skouteris $H$, et. al. How well do women adapt to changes in their body size and shape across the course of pregnancy? J Health Psychol 2008;13:503-15.

33. Kartal B, Kızılırmak A, Zedelenmez A, et. al. Investigation of body perception in pregnant women according to physical changes in pregnancy. J Contemp Med 2018;8:356-60.

34. Coskun AM, Arslan S, Okcu G. An analysis of pregnancy perception of pregnant women in terms of stress, demographic and obstetric characteristics. HEAD. 2020;17:1-8.

35. Ucar $\mathrm{H}$. The relationship between the psychosocial health status of pregnant women and the role of motherhood. Master's thesis, Ataturk University, Erzurum, 2014.

36. Kumcagiz H, Ersanli E, Murat, N. The Development of a Self-perception of Pregnants Scale and its Psychometric Features. J Psychiatric Nursing 2017;8:23-31.

37. Ozkan A, Arslan H. Decision on pregnancy, perception of physiological complaints and education needs. Zeynep Kamil Medical Bulletin 2007;38:155-61.

38. Chang SR, Chao Y, Kenney NJ. I am a woman and I m pregnant: Body image of women in Taiwan during the third trimester of pregnancy. Birth 2006;33:147-53.

39. Kucukkaya B, Altan Sarikaya N, Kahyaglu Sut H, et al. The relation between body perception related to the weight gain during pregnancy and acceptance of pregnancy. Jaren 2020;6:426-32. 